\begin{tabular}{|l|l|l||}
\hline \multicolumn{2}{|c|}{ PublisherInfo } \\
\hline \hline PublisherName & $:$ & BioMed Central \\
\hline \hline PublisherLocation & $:$ & London \\
\hline \hline PublisherImprintName & $:$ & BioMed Central \\
\hline \hline
\end{tabular}

\title{
Gene fusion identified in prostate cancer
}

\begin{tabular}{|l|c|l||}
\hline \multicolumn{2}{|c|}{ ArticleInfo } \\
\hline \hline ArticleID & $:$ & 5043 \\
\hline \hline ArticleDOI & $:$ & $10.1186 /$ gb-spotlight-20051102-01 \\
\hline \hline ArticleCitationID & $:$ & spotlight-20051102-01 \\
\hline \hline ArticleSequenceNumber & $:$ & 106 \\
\hline \hline ArticleCategory & $:$ & Research news \\
\hline ArticleFirstPage & $:$ & 1 \\
\hline \hline ArticleLastPage & $:$ & 3 \\
\hline \hline & & RegistrationDate : 2005-11-2 \\
\hline ArticleHistory & $:$ & OnlineDate \\
\hline \hline ArticleCopyright & $:$ & BioMed Central Ltd2005-11-2 \\
\hline \hline ArticleGrants & $:$ & \\
\hline \hline ArticleContext & $:$ & 130595511 \\
\hline \hline
\end{tabular}




\section{Ishani Ganguli}

Email: iganguli@the-scientist.com

Using a novel bioinformatics approach, researchers found that the majority of prostate cancers carry a specific gene fusion, a common feature of blood cancers but relatively rare in solid tumors, according to this week'sScience. A team led by Arul Chinnaiyan found that in over $75 \%$ of prostate cancer samples, the regulatory region of the TMPRSS2 gene is fused to a gene encoding an ETS transcription factor, either $E R G$ or $E T V 1$, causing over-expression of the factor and, in turn, cancerous growth.

"There was a general consensus that the mechanism [of] translocation was not [found] in the major types of epithelial tumors," said Stephen Baylin at Johns Hopkins Medical School in Baltimore, Md., who did not participate in this study. "This is a big sort of hint that functional translocations are much more common in solid tumors. That's a fascinating step."

Chinnaiyan's lab at the University of Michigan Medical School had previously created Oncomine, a publicly available database for human cancer gene expression data which, to date, integrates 132 data sets from 10,486 individual tumors. To investigate potential genetic causes of prostate cancer, the group developed and applied cancer outlier profile analysis (COPA) to a subset of this microarray data, identifying genes with an unusually high degree of over-expression.

Out of the top ten outlier genes, the researchers focused on the two known to cause other forms of cancer, ERG and ETV1. Both genes code for ETS family transcription factors that regulate cell growth and proliferation, and are involved in oncogenic translocations in both Ewing's sarcoma and myeloid leukemia. In these cancers, translocation of each transcription factor is functionally redundant, so that either one or the other is found in any given tumor.

The researchers showed the same mutual exclusivity exists in prostate tumors, suggesting that $E R G$ and ETVI might play similar roles in prostate cancer. In over $90 \%$ of the prostate tumors that overexpressed one of these genes, they discovered that this gene was fused to the upstream un-translated region of TMPRSS2, the androgen-regulated protease gene primarily found in prostate tissue.

Using fluorescence in situ hybridization, the researchers found that 23 out of 29 tumors - close to $80 \%$-- that were not pre-selected contained this translocation. "What's so remarkable about this is the frequency with which they found [the same rearrangement]," said Janet Rowley at the University of Chicago Medical Center, given that carcinomas usually contain random, nonspecific chromosomal changes.

When the researchers exposed prostate cancer cell lines with the TMPRSS2:ERG fusion to androgen, they found greater $E R G$ expression, suggesting that the androgen-sensitive promoter elements of TMPRSS2 mediate over-expression of the transcription factors. Doctors currently treat prostate cancer by inhibiting androgens; this finding helps explain why such treatments work, and "may allow us to fine tune" current therapeutics, Baylin said.

Chinnaiyan told The Scientist that these findings point to another potential avenue for treatment: using small molecules to inhibit $E R G$ and ETV1 over-expression. As the only gene alteration found in the majority of prostate cancers, this translocation could also serve as a marker to test men for the disease, he said, a molecular diagnostic strategy that is potentially more accurate than measuring PSA levels. 
In addition, this work "raises the question as to what other solid tumors also have translocation [of these genes]," said Rowley, who did not participate in the study. "We don't think that prostate cancer is necessarily special," Chinnaiyan added. He added that he plans to extend his bioinformatics approach to look for causative gene rearrangements in other solid tumors, such as breast cancer.

\section{References}

1. S. A. Tomlins, et al., "Recurrent Fusion of TMPRSS2 and ETS Transcription Factor Genes in Prostrate Cancer" Science, 310: October 28, 2005, [http://www.sciencemag.org]

2. Arul Chinnaiyan, [http://www.pathology.med.umich.edu/dynamo/chinnaiyan/ bioSketch.jsp?uid=arul]

3. Stephen Baylin, [http://www.hopkinsmedicine.org/graduateprograms/cmm/baylin.html]

4. Oncomine- Cancer Microarray Database, [http://www.oncomine.org]

5. A. Chinnaiyan, "Oncomine and caBIG Advance Cancer Bioinformatics," The Scientist, April 11, 2005, [http://www.the-scientist.com/2005/4/11/22/1]

6. Janet Rowley, [http://biomed.bsd.uchicago.edu/faculty/rowley.html] 